\title{
Epistemik Öznenin Ontik Ben İdraki: Eğitime Metafizik Bir Anlam Kazandırmak
}

\section{Ontic Apperception of an Epistemic Subject: Giving Education a Metaphysical Meaning}

\author{
Ahmet Erhan Şekerci* ${ }^{\star}$
}

Öz

Bu çalışmamızda, varlık olarak insanın, ontik ve epistemik yönden, eğitim eylemindeki yerini ele almaya ve metafizik bağlamda değerlendirmeye çalışacağız. Düşünce tarihinde çokça sorulan ve bir o kadarda farklı ve derinlikli boyutları olan 'insan nedir?' sorusunu merkeze alıp, insanın öğrenebilen bir varlık olması açısından konuya yaklaşacağız. Eğitim ve insan ilişkisinin rasyonel ve teknik boyutlarının yanında, insan olmaklık eyleminin içeriğini ifade eden metafizik bakış açısıyla, söz konusu ilişkinin boyutunu ontik ve epistemik yönden sorgulayacağız. Aristo'nun 'var olmak bakımından varlığın bilimi' olarak nitelendirdiği metafiziği, varlığın en önemli temsilcisi olan insanı merkeze alarak, insan ve eğitim ilişkisinin anlamına yeniden dikkat çekmeye çalışacağız. Hem öğrenen, hem de öğreten bir varlık olarak insanın, ilk öğrenci ve öğretici rolünü ve mümkün varlık olarak metafizikle kurduğu ilişkiyi eğitim bağlamında tartı̧acağız. Konuyu daha çok, din eğitimi özelinde ele alıp, insanın eğitimle olan ilişkisini dini ve metafizik bir öz üzerinden, niteliğe dayalı bir yapı içinde izah etmeye çalışacağız.

\section{Anahtar Kelimeler}

Eğitim, Öğrenme, İnsan, Metafizik, Ontik, Epistemik

\begin{abstract}
This study aims to conduct a metaphysical examination of the significance of humans in education within the ontic and epistemic contexts. It focuses on the question of What is human being?, which has been discussed extensively from various dimensions. Furthermore, the study analyzes the subject in terms of the concept of mathesis. In addition to the rational and technical dimensions of education and interpersonal relations, this study introduces the ontic and epistemic dimensions of the subjects and, thus, bring forward a metaphysical view. The main objective is to draw attention to the meaning of the relationship between humans and education by focusing on the Aristotelian metaphysics of being qua being and taking the human being as the center and the most important representative of existence. This study begins by discussing Aristotle's idea that man is an object and a subject of education before discussing his idea of man's relationship with metaphysics vis-à-vis education. Lastly, this study considers the aspect of religious education and explains the attachment of man to religion.
\end{abstract}

\section{Keywords}

Education, Learning, Human, Metaphysic, Ontic, Epistemic

\footnotetext{
* Sorumlu Yazar: Ahmet Erhan Şekerci (Doç. Dr.), İstanbul Üniversitesi, İlahiyat Fakültesi, Felsefe ve Din Bilimleri Bölümü, İstanbul, Türkiye. E-posta: ahmetsekerci@istanbul.edu.tr ORCID: 0000-0001-5130-8564
} 


\section{Extended Summary}

This study examines the human condition from the perspective of education and provides a metaphysical justification for humanity's character regarding education by investigating the ontic and epistemic conditions of human being, as a being receptive of education. Humans are the only beings that follow a conscious process of education through which they advance and become aware of their ontological state. Given their rationality, humans differ from other animals, which are guided by instincts. Thus, learning and teaching are essential to humanity due to its rational and spiritual dimensions.

The world is continuously changing, and humans require constant self-improvement, which renders education indispensable. To find its proper place in the unchanging world, man needs a metaphysical outlook. Hence, the metaphysical foundation of educational activities is justified. This foundation is closely connected to the duality that characterizes humanity, that is, the duality of soul and body, which indicates that man is connected to the metaphysical and material essences. Thus, an educational program that properly addresses this duality will be enduring and efficient. Throughout history, one may find religious and philosophical teachings that identify the dual aspect of man and place emphasis on the metaphysical essence. For example, Christians state that man reflects the image of God, whereas Muslims believe that the soul is Allah's vicegerent on earth.

Man has the capability to learn, will, believe, think, and reason. Therefore, he is an agent and object of education. Certainly, Adam is a good example in this regard. By receiving divine wisdom, Adam was the first student as well as the first teacher of humanity. Humans, as progenies of Adam, became the only creature that can establish a metaphysical connection with its creator and improve itself through education. Adam is also the first product of man's metaphysical dimension in that he underwent a selfconscious educational activity. In this regard, the concept of being an Adam expresses the symbolic dimension inherent in the process of man's self-realization.

Education is a life-long process, which aims to guide man by improving its experience, manners, and abilities. Metaphysics involves an inquiry into being qua being. Therefore, education helps humans to conduct this inquiry properly. Education is also an important element of the metaphysical truth. Being human is to be a being that can learn. The ontic and epistemic heights of man are, therefore, possible only if humans acquire metaphysical consciousness and personal mental independence.

The most important aspect of educational activity is to provide the individual with mental freedom, that is, enabling humans to become aware of themselves as moral agents. For education to be maintained and yield results that conform to human values, educational institutions should uphold moral values. In the contemporary world, education is not simply the transmission of information from one generation to another. Instead, it may be 
considered a means for helping people develop their personal identity in connection with metaphysical ideals. However, this manner of understanding education is problematic, especially in religious education and education in the humanities. The reason behind this notion is that the conformist and ideological perspectives lead to the loss of the ontological dimension of education, which transforms education into an instrumentalization at best and a dangerous weapon at worst. For this reason, the metaphysical foundation of education in relation to the realization of humanity should be carefully considered.

Educational activities play an important role in humanity's construction of civilizations. Throughout history, humans continue to bend nature to their will through education. The practical and technical dimensions of educational activities are considered sufficient for highlighting the metaphysical dimension of education. This study argues that this perspective of education is crucial to understanding the many problems of humanity in the past, present, and future. Every ideological or political movement has certain ideals concerning human beings. Therefore, any thought or activity devoid of meaning that complies with these ideals poses a significant danger to humanity. Ideological and political movements adopt this strategy to guarantee their subsistence. Thus, educational policies reflect certain ideological paradigms that underlie the milestones of human civilization.

However, interestingly and ironically, satisfactory results were never achieved throughout history despite efforts and policies regarding humanity and education to satisfy human expectations. The reasons for this failure are hidden in human existential conditions. Other suggestions and applications eliminated and rendered useless the responses to these problems and strategies developed under certain spatiotemporal conditions. The ideological and political limits of such responses and strategies, their emphasis on quantities, and the achievement of fast results in theory and practice led to various forms of mental destruction in the generations that were subject to them. This scenario may then be identified as the major cause of mental and physical disasters as a result of wars. Given these facts, one should accept that activities that do not acknowledge the moral values of humanity and, as such, deviate from the metaphysical dimension of humanity, are considered destructive.

The educational perspectives developed during the Enlightenment centralized humanity and assigned a dominant role to it in the relationship between human beings and nature. Such a dominant role was never assigned to humanity in history. However, during the 19th and 20th centuries, humanity did not only enjoy the good opportunities provided by the age of knowledge but also witnessed global disasters. In our time, humanity has totally lost its world of meaning with which it makes sense of its existence or has attempted to find meaning in certain deceptions. Thus, humanity has lost its metaphysical perspective. These notions are seemingly a result of the polarization between ideological 
engagements that oscillate between the absolute and nothingness and quantity-centered educational policies, both of which seem unlikely to be overcome.

Thus, this study points out that human beings are rational and have free will. Human beings can learn, teach, govern, and be governed, due to their rational and spiritual capabilities. However, quantity-centered educational techniques, given their reductive and marginalizing ideological strategies, will only lead humanity to cut ties with the existential world of meaning and transform humans into mere objects of education without orientation. The solution to this problem is addressing the causes in an appropriate manner. In other words, educational activities should be established with an awareness of the meaning of human existence and in relation to the metaphysical dimension of human existence with consideration of the relevant ontic and epistemic conditions. Thus, this study investigates how human beings should be educated, such that the metaphysical dimension of human existence is also appropriately emphasized. 


\section{Giriş}

İnsanoğlunun doğada var olma sürecine baktığımızda, hızlı, kontrolü zor, kazandırdıklarıyla kaybettikleri çok olan, ama daima sorgulanmaya muhtaç bir ilerlemenin içinde olduğunu görürüz. Çağdaş dünyanın, teknik ve yenilikçi yüzüyle her gün bizlere sunduğu imkânlar, başta öğrenme faaliyetlerimiz olmak üzere hayatımızın her alanını geri dönülmez bir şekilde değiştirmektedir. Değişimin mutlak olduğu bu alemde, hayatımızı yönlendirecek sabitelere ulaşmak için, insanın kendini sorgulaması ve eğitim faaliyetlerini bu bağlamda inşa etmesi gerekmektedir. Değişimi anlamak ve onu yöneten değişmeze ulaşmak için, insanın kendini anlamlandırma serüveninin metafizik boyutunun önemi yadsınamaz. $\mathrm{Bu}$ çalışmamızın en temel argümanı insanın öğrenebilen bir varlık olmasıdır. Bu dünyada doğa ile ilişki kurup onu şekillendiren, yöneten ve inşa eden insanoğlunun varlık mücadelesinin temelinde, onun öğrenme eyleminin sağladığı avantaj vardır. Buna bağlı olarak, 'insan nedir?' ve 'insan olmanın bir anlamı var mıdır?' soruları düşünce tarihinde cevabı en çok aranan sorulardan olmuştur. Teolojilerin ve felsefelerin bu ve buna benzer sorulara verdikleri cevaplarda birbirini tamamlayan bazı benzer ve destekleyici unsurlar bulunmaktadır. Düşünce tarihinde ve teolojilerde insan varlığı genellikle beden ve ruh birlikteliğinden müteşekkil bir dualite ile açıklanmıştır. ${ }^{1}$ Yine insan bu dünyadaki eylemlerini yöneten ve onu diğer varlıklardan ayrı kılan akıl yetisiyle donatılmış bir canlı olarak da nitelendirilmiştir. Ayrıca semavi teolojiler içinde insanın varlıklar içindeki yeri, yaratıcı güç ile doğrudan ilişki kuran ya da bizatihi onun yansıması olan metafizik bağlamda izah edilmeye çalışılmıştır. Hıristiyanlıkta insan, Tanrı'nın bu dünyadaki yansıması, Müslümanlar içinse, Allah'ın yeryüzündeki halifesidir. Ontik olarak insan, mümkün varlıklar içinde en üstünü aynı zamanda Tanrısal öze ve ilişkiye sahip tek varlık olarak ifade edilmiştir.

İnsan öğrenebilen bir varlık olduğu gibi aynı zamanda doğal olarak inanabilen bir varlıktır. İnanma eyleminin teistik, deistik ya da başka türlü olma imkânı her zaman için vardır. Ancak tabiat olarak insanın nasıl bir varlık olduğunun bilinmesi onun eğitim faaliyeti içerisindeki yerinin anlamlandırılması bakımından oldukça önemlidir. Bu nedenle çalışmamız iki ana kısımdan oluşmaktadır. Birinci kısımda öğrenme eylemi ve insan başlığı altında insanın öğrenebilen bir varlık olma durumunu tartışmaktayız. Bu tartışmamızın ana eksenini ise 'insan nedir?' sorusu şekillendirmektedir. Akıllı ve iradi bir varlık olarak insanın diğer varlıklar içindeki yerini, varlık olarak bizatihi kendi yapısını, birinci bölümde ele alacağız.

1 Platon, Phaidon (Ruh Üstüne), çev. Nazife Kalaycı (İstanbul: Kabalcı Yayınevi, 2012), 119-120 (79b-d); Aristoteles, Ruh Üzerine, çev. Ömer Aygün ve Y. Gurur Sev (İstanbul: Pinhan Yayınları, 2019), 99 (414a14-27); René Descartes, Ruhun İhtiraslarl, çev. Mehmet Karasan (İstanbul: Milli Eğitim Bakanlığı Yayınları, 1997), 6. 
İkinci kısımda ise epistemik yönünün anlam kazanmasını sağlayan ontik yönü üzerinden insana dair bir bakış açısını ortaya koymaya çalışacağız.

İnsan kavramı beşer anlamına gelen Arapça 'ins' kelimesinden türemiştir. ${ }^{2}$ Unutma anlamına gelen ve insanın yaratıcısıyla olan sözleşmesine de atıfta bulunan bu kök aynı zamanda üns masdarı ile alışmak ve uyum sağlamak bağlamında insan ve eğitim ilişkisine de vurgu yapmaktadır. İnsan fani olmak anlamında beşer ve bilmeklik ve yaratılma anlamında Âdem kavramlarıyla da kullanılmaktadır. Ayrıca sözlükte dik duran, iki eli ve ayağı olan memeli bir canlı olarak nitelenmiştir. Vasıf olarak çok gelişmiş, konuşabilen, sözle anlaşabilen, aklı ve düşünme yeteneği olan en gelişmiş canlı, beşer olarak da ifade edilen tür olarak homo sapien olan canlıdır. ${ }^{3}$ Tüm bu anlamlar aslında çalışmamızda konu edindiğimiz insanın ontik ve epistemik yönünün teolojik ve kadim kullanımlarında da var olduğunu göstermektedir.

Teolojik ve çoğu felsefi görüşe göre, yaratılmış/mümkin bir varlık olan insan, ruhî özelliklerinden dolayı, külli bir yok olmaya uğramayacak olan bir varlıktır. Kur'an-1 Kerim'de ilk insanî özellikleri üzerinde taşıyan Hz. Âdem, tüm bu hususlara dair ortaya konulabilecek ilk ve en iyi örnektir. Âdem, Allah'ın yaratıp halifesi yaptığı ve kendi ruhundan üflediği, hikmeti bahşettiği ve meleklerin kendisine secde edilmesini istediği mümkün bir varlıktır. İnsani bağlamda maddenin ruh ile buluştuğu ilk örnektir. Beşer olarak Âdem artık, canlı, mümkün, öğrenebilen, irade edebilen ve konuşabilen ilk varlık yani ilk öğrenci konumundadır. ${ }^{4}$

Allah'ın insana beyanı öğretmesi, O'nun ilk öğretmen, insanın da ilk öğrenci olduğunu göstermektedir. Aslında ontik ve epistemik boyutun metafizik bağlamda vücuda geldiği yer tam burasıdır. Zamanla insanın doğaya karşı kazanımları, bu anlamın zayıflamasına ve beşeri/geçici/ölümlü yönünü unutmasına neden olmuştur. Eğitim ve insan ilişkisi, statik ve adeta determinist bir yapıya büründürülerek, yığınları kontrol eden bir güç, çoğunlukla da bir problem haline dönüştürülmüsstür. İnsanoğlunun huy ve eğilimleri eğitim ve iyi alışkanlıklar sayesinde değişime uğramaktadır. Gerek antik dünyada gerekse İslam düşüncesinde bu vurgu her zaman canlı tutulmuştur. Ancak günümüzün modern dünyasında, sahip olunan imkânlara bağlı olarak ortaya çıkan eğitimin çıktıları, insan olmaklık bakımından ve en önemlisi anlamın temelini ifade eden metafizik bağlamdan uzaklaştırılarak temellendirilmeye

2 İlhan Kutluer, “İnsan”, içinde TDV İslâm Ansiklopedisi (Ankara: Türkiye Diyanet Vakfı Yayınları, 2000), 320.

3 Yaşar Çağbayır, Ötüken Türkçe Sözlük, c. 2, 5 c. (İstanbul: Ötüken Yayınları, 2007); Çağbayır, 2:2187. Çağdaş dünyada homo sapien kullanımı, daha çok biyolojik evrim kuramı bağlamında ele alınmaktadır. bk. Edward O. Wilson, İnsanın Varlığının Anlamı, çev. Zeynep Sezer (İstanbul: Olvido Yayınları, 2017), 16.

4 er-Rahman 55/4. el-Araf 7/11; el-Hicr 15/26, 28-29; er-Rahman 55/4. 
çalışılmaktadır. Görülmüştür ki, anlamdan uzak, amaçsız nesillerin yetişmesi, geleceği inşa etme niyetiyle yürürlüğe konulan eğitim politikalarının nihayetinde bir fiyaskoyla sonuçlanmasına neden olmuştur. Unutulmamalıdır ki, eğitim insanın doğumundan ölümüne kadar devam eden bir vetiredir. ${ }^{5} \mathrm{Bu}$ vetireyi kontrol eden gelenek ve zihniyetin metafizikle olan ilişkisini işlevsellik yerine, niceliksel ve popüler amaçlara göre inşa etmek, amaçlanan bilgi, beceri, tutum ve değerlerin çözüm olmaktan öte bizatihi problemin kaynağı olma ihtimalini yükseltmektedir. $\mathrm{Bu}$ nedenle yeniden ontik anlama dönüp insan olduğumuzu hatırlayıp, eğitim yoluyla yeniden bunu işleyip, yeni nesillere anlatmamız gerekmektedir. Tıpk1, Platon'un (ö. M.Ö. 348) işaret ettiği gibi ‘Sadece İnsan Olduğunu Bil”ebilmek ${ }^{6}$ için, yeniden epistemik bir çabaya ihtiyacımız vardır. Eğitimle inşa edeceğimiz geleceğin, insan üzerinden metafizik anlamla buluşabilmesi için, Sokrates'in (ö. M.Ö. 399) deyimiyle, kendimizi bilmeye, aslında pek bir şey bilmediğimizin farkına varmaya ve hayatımızı sorgulamaya başlamalıyız. ${ }^{7}$

\section{1. Öğrenme Eylemi ve İnsanın Varlığı Üzerine}

\subsection{Varlık Olarak İnsan: İnsan Nedir?}

Akıl sahibi varlık olarak insan, iradî ve bilinçli/şuurlu öğrenme eyleminde bulunabilen bir canlıdır. O tarihin her devrinde kendini geliştirmek ve mükemmelleşmek adına eğitilen/eğitilebilen bir varlıktır. ${ }^{8}$ Kur'anî bir söylemle ifade edersek eğer, bir Âdem olan insan, aslında bu alemdeki ilk bilinçli varlık ve öğrencidir. Âdem aynı zamanda Tanrı'nın ona verdiği hikmet gereği, isimleri bilen, öğrenebilen, öğretebilen ve eğitimle bu dünyada yaşam kurabilen ilk varlıktır. ${ }^{9} \mathrm{O}$ iradî bir varlık olarak, içgüdüsel olan diğer tüm varlıklardan ayrışmaktadır. İslam'a göre, Allah'ın bu alemdeki halifesidir. ${ }^{10}$ Dini literatürde böylesine önemli bir konuma sahip olan insanın özellikleri hususunda düşünce tarihine baktığımızda, hem filozofların hem de teologların, benzer fikirler ortaya koyduklarını görmekteyiz.

5 Münire Erden, Ĕgitim Bilimlerine Giriş (Ankara: Arkadaş Yayınları, 2011), 13.

6 Walter Kranz, Antik Felsefe, çev. Suat Baydur (İstanbul: Sosyal Yayınları, 1984), 25.

7 Platon, "Kharmides", içinde Diyaloglar, çev. Tanju Gökçöl (İstanbul: Remzi Kitabevi, 2010), 312 (165b); Platon ve Teoman Aktürel, “Sokrates'in Savunması", içinde Diyaloglar (İstanbul: Remzi Kitabevi, 2010), 15, 17, 34 (21d, 23c, 38a).

8 Mustafa Ergün, Eğitim Felsefesi (Ankara: Pegem AkÂdemi, 2015), 2.

9 el-Bakara 2/33. Bu ayette Allah'ın Âdem'e eşyanın isimlerini öğretmesi ve bilgi ile onu yüceltmesi anlatılmaktadır. İnsanın yüceliğinin Tanrı'dan geldiğini ve bizatihi Tanrısal bilginin insana bahsedilen kısmının bile, meleklerin secde etmesinin anlamı, bilgi ve eğitim ilişkisi bakımından irdelenmesi gereken bir husustur.

el-Bakara 2/30. 
İnsanı diğer varlıklardan ayrıştıran unsurların daha çok, akıl ve ruh kavramlarıyla ifade edildiğini görmekteyiz. Yine bu insan, irade sahibi, içgüdüsel olarak hareket etmeyen, kendini geliştirebilen, eğitimin hem öznesi hem de nesnesi olan bir varlıktır.

İnsan bilinçli şekilde öğrenme eylemini gerçekleştirebilen ve sürdürebilen bir varlıktır. Bu öğrenme eylemi onu hem fiziki hem de metafizik anlamda diğer varlıklardan ayıran bir imkân ve anlamın doğmasını sağlamıştır. Bu anlamın en önemli boyutları kuşkusuz özgürlük, ahlaki varlık olma ve sorumluluktur. İnsan akleden, değer üreten, medeniyet kuran, seçebilen bir varlıktır. Bilinçli bir eğitim öznesi olan insan, amaçlanan eğitim çıktılarına göre kendini şekillendirebilen ama diğer canlılar gibi kesin sınırlamalara sokulamayan bir canlıdır.

Antikçağ, Ortaçağ, İslam ve Batı dünyasında ‘insan nedir?' sorusunun cevabı, çoğu filozofta karşımıza çıkan, 'insan akıl ve ruh sahibi bir canlıdır' açılamasına indirgenecek kadar öz bir cevaptır. Ancak Rönesans, Aydınlanma ve evrim anlayışının etkilediği bakış açıları ve yakın zamanda insanı antropolojik olarak ele alan düşünürler, bu klasik bakış açısına daha derinlemesine ve kategorik bir sınıflamayla bakmaya başladılar. Teistik dinlerin insana yüklediği metafizik anlam, özellikle Nietzsche (ö. 1900) gibi düşünürlerin etkisiyle, ciddi eleştirilerin muhatabı haline geldi. Öyle ki, insanın diğer varlıklar gibi bilimin ve akli soruşturmanın konusu yapılması, çağlar boyunca insan dair oluşan epistemolojinin ve anlam dünyasının ciddi bir şekilde sarsılmasını ve belli oranda da yıkılmasını sağladı. Aklın klasik kullanımında yaşanan bu değişim, onun bilimsel araçsal akla yönelmesine sebep olmuştur. ${ }^{11}$ Özellikle insanî evrim sürecinin son temsilcisi kabul edilen ve homo sapien olarak vasfedilen insanın ne olduğuna dair evrimci bir bakış olmadan, bazı kesimlerce diğer tüm açıklamalar tamamen ya yadsındı ya da anlamsızlaştırıldı. ${ }^{12}$ Özellikle Max Scheler (ö. 1928) ile başlayan antropolojik yaklaşımlar, ülkemizde Takiyyettin Mengüşoğlu (ö. 1984), İonna Kuçuradi ve Muttalip Özcan gibi düşünürlerce, klasik düalist bakış açısının şekillendirdiğinden farklı olarak oldukça kategorik bir sınıflamaya tabi tutuldu. Benzer bakış açısının Batı'daki başlıca temsilcisi Nietzsche'dir. Düşünürün üçlü insan sınıflandırması bu açıdan oldukça dikkat çekicidir. Kant'ın (ö. 1804) akıl üzerinden insana dair yaklaşımı, ahlak metafiziği açısından ortaya koyduğu bakış açısı, klasik insan anlayışını kısmen hatırlatsa da Kant, Schopenhauer (ö. 1860), Hegel (ö. 1831), Marx (ö. 1883) ve Nietzsche ile kabul gören yeni bakış açıları ciddi birikim ve sonuçlarıyla düşünce dünyamızda yerini almıştır.

11 Muttalip Özcan, İnsan Felsefesi: İnsanın Neliği Üzerine Bir Soruşturma (Ankara: Bilgesu Yayıncılık, 2016), 330.

12 Wilson, İnsanın Varlı̆̆ının Anlamı, 18-19. 
Düşünce tarihinin en anlamlı sorularından olan 'insan nedir?' sorusunun ilk ciddi cevabını antik dünyada bulmak mümkündür. İnsan akıl ve ruh sahibi bir canlıdır. Bu iki özelliği irade ile birleştiğinde özgürleşebilen, bilinçli bir şekilde öğrenebilen bir varlıktır. Bu durum bizatihi insan olmaklık durumuyla ilişkilidir. Sokrates'in insanın kendini bilmekle ruhunu bilmeyi özdeş kabul etmesi bu bakış açısını yansıtmaktadır. ${ }^{13}$ Zira düşünüre göre insan olmanın en önemli yönü akıl sahibi olmaktır. İnsan kendine sorulan akli sorulara yine akli olarak cevap verebilen bir varlıktır. ${ }^{14}$ Bunlardan dolayı o sorumlu, yani ahlaksal bir özne konumundadır. ${ }^{15}$ Sokrates'de karşımıza çıkan insan görüşü, külli/bütüncül bir bakışın ifadesidir. Bu nedenle kategorik insan bakışlarının tüm unsurlarını da, aslında bu bütüncül bakışın içinde bulmak mümkündür. Bu açıdan M. Özcan'nın ifade ettiği kavramsal, kişi ve birey olarak insan sınıflandırmasının unsurlarını Sokrates'te bulmak mümkün olduğu gibi ${ }^{16}$ tarihsel süreçte pek çok düşünür için aynı sınıflandırmaların benzerlerini yapmak da mümkündür. Ancak biz çoğu kategorik bakış açısının içine düştüğü indirgemecilik tehlikesine binaen bütüncül bakış açısının korunması ve insana dair düşünce dünyasının yine bu noktadan ihya edilmesi gerektiği kanaatindeyiz. Düşünce dünyasının ilk sistem filozofları olan Platon ve Aristo'nun (ö. M.Ö. 322) insana bakışı ruh ve akıl temellidir. Ruh doğal cismin ilk yetkinliğidir. Canlıyı cansız olmaktan ayıran şeydir. Akıl ise bu canlılık halinin bilinç ve irade şeklinde eğitime konu olan tarafımızın ortaya çıkmasını sağlayan şeydir. Ama varlık olarak insanda akıl ve ruhun birbiriyle uyumu söz konusudur. ${ }^{17} \mathrm{Bu}$ özellikler sıradan insan olma imkânının asgari şartlarını sağladığı gibi, yine aynı özelliklerin işlenmesiyle iradi ve ahlaki bir varlık olmak ve kendini gerçekleştirmek imkânına bağlı olarak erdemli ve bilge bir insan olma imkânı da her zaman vardır. ${ }^{18}$ Platon için zaten bunun en müşahhas örneği hocası Sokrates’tir. Antik dünyada Platon ve Aristo insan1, toplumun ve medeniyetin en önemli unsuru olarak, siyaset ve ahlak bağlamında ele almışlardır. Ruha sahip bir varlık olarak, aklın erdemle olan ilişkisi, bizi erdemle birleşen bilge insan formuna götürmektedir. Aynı durum siyaset düşüncesine

13 Kadir Canatan, İnsan Felsefesi (İstanbul: Beyan Yayınları, 2018), 12.

14 Ernest Cassirer, Insan Üstüne Bir Deneme, çev. Necla Arat (İstanbul: Remzi Kitabevi, 1980), 17.

15 Kranz, Antik Felsefe, 25.

16 Özcan, Insan Felsefesi, 9.

17 Aristoteles, Nikomakhos'a Etik, çev. Saffet Babür (Ankara: Ayraç Yayınları, 1997), 11 (1098a520).

18 Platon, "Gorgias", içinde Diyaloglar, çev. Melih Cevdet Anday (İstanbul: Remzi Kitabevi, 2010), 65-66 (463e, 464a-b); Platon, “Menon”, içinde Diyaloglar, çev. Adnan Cemgil (İstanbul: Remzi Kitabevi, 2010), 175 (89a); Platon, Phaidon (Ruh Üstüne), 61-63 (65b-d); Aristoteles, Ruh Üzerine, 35,87,89,103 (403a3, 412a6, 412a11, 412a20, 414b19). 
de yansımıştır. ${ }^{19}$ Hem Platon hem de Aristo için, ruhunun akla ve erdeme göre eylemde bulunması onu üstün kılacaktır. Ancak yine aynı insanın, sahip olduğu aklı ve iradeyi yanlış kullanıp bunun tam tersi bir eylemde de bulunma ihtimali her zaman vardır. Tarih aslında etik bağlamda uygun olmayan örneklerin çokluğuyla doludur. Bu nedenledir ki, çağdaş yaklaşımlarda tür olarak insanın sahip olduğu akıl ve ruhun, insani eylemler bakımından bireysel tasarrufları sinıflandırmada yeterli olmadığ 1 görülmüştür. ${ }^{20} \mathrm{Bu}$ nedenle kendini gerçekleştirebilen insanlar üstün, özgür, yaratıc1, ${ }^{21}$ trajik ve üstinsan ${ }^{22}$ tanımlamalarıyla ifade edilmiştir. Ancak unutulmaması gereken şey bütüncül şekilde meseleye yaklaştığımızda tür olarak insanın potansiyel bağlamda diğer tüm sınıflamaları da gerçekleştirebilme imkânına sahip olduğudur. Klasik dünyada karşımıza çıkan ve özellikle Platon ve Aristo'nun fikirlerini inşa ettiği Atina toplumunun söz konusu özellikleri kullanma bakımından farklı olduğunu bilmek gerekiyor. Zira 'insan nedir?' sorusuna verilen cevabın muhatabı olan Atina toplumunda muhataplığın sadece özgür erkekler üzerinden kurulduğunu bilmek gerekmektedir.

İslam düşüncesinde başta Fârâbî (ö. 950), İbn Sînâ (ö. 1037), İhvan-1 Safâ ve diğer çoğu İslam filozofunda klasik akıl ve ruh ayrımı varlığını genişleyerek korumuştur. Bu anlayış Ortaçağ boyunca varllı̆ıııı sürdürmüş, günümüzde de, biraz sonra bahsedeceğimiz felsefî antropoloji bağlamında ya da bilimsel ve ideolojik bazı bakış açıları haricinde, eski etkinliği olmasa bile teistik din mensuplarında varlığını sürdürmektedir. İslam düşüncesinde nefs anlayışı bağlamında insanın hem maddi hem de ruhi yapısı, bir bütünlük içinde ele alınmıştır. Fârâbî’de ay altı alemde oluş ve bozuluşa tabi varlıklardan biri olarak kabul edilen insan, dil ve düşünce sahibi nâtık bir canlı/hayvan olarak nitelendirilmiştir. Ayrıca insanın ruh sahibi olması onun bilgi edinmesinin en önemli aracıdır. Nitekim ruh sahibi olan insan mütehayyile gücü ile önceden algıladığ 1 şeylerin izlerini ruhunda hissedebilmektedir. ${ }^{23}$ İbn Sînâ’ya göre düşünen olabilmek için, öncelikle nefs

19 Platon, Devlet, çev. Sabahattin Eyüpoğlu ve M.Ali Cimcoz (İstanbul: Remzi Kitabevi, 1992), $122-123$ (433a-d).

20 Özcan, İnsan Felsefesi, 14.

21 İonna Kuçuradi, Nietzsche ve İnsan (İstanbul: Yank1 Yayınları, 1967), 12-14.

22 Friedrich Nietzsche, Böyle Söyledi Zerdüşt, çev. Mustafa Tüzel, Hasan Âli Yücel Klasikler Dizisi (İstanbul: Türkiye İş Bankası Kültür Yayınları, 2016), 6-7.

23 Ebu Nasr el-Fârâbî, İdeal Devlet: "el Medinetü'l Fâzıla", çev. Ahmet Arslan (Ankara: Divan Kitap, 2015), 53,73,75; Gürbüz Deniz, İnsan Hürriyetinin Metafizik Temelleri (İstanbul: Litera Yayınc1lık, 2017), 27. 
sahibi olmak gerekmektedir. ${ }^{24}$ Nitekim Aristo'cu geleneğe vurgu yapan, ${ }^{25}$ 'insan düşünen bir canlıdır' tanımlamasındaki kasıt, idrak eden bir nefs sahibi olan canlıdır anlamına gelmektedir. ${ }^{26}$ Aynı geleneğin eklektik bir devamı olan İhvan-1 Safâ'da insan, beden ve ruhtan mürekkep bir varlıktır. Mutlak manada ilk eğitimci olarak kabul edilen yüce yaratıcı büyük alemi temsil ederken, bu alemde yaratılmış olan insan küçük alemi temsil etmektedir. ${ }^{27}$

‘İnsan nedir?’ sorusuna klasik yaklaşımın dışında özellikle felsefi antropoloji, ya da bütüncül bakış açısından farklı olarak kategorik bir şekilde sınıflandırma çabası yirminci yüzyılda bizatihi insanın felsefenin ana konusu olmasıyla hızlanmıştır. Ülkemizde ilk defa Mengüşoğlu ve Kuçuradi'nin insan üzerine ortaya koydukları görüş ve sınıflandırmalar, ayrıca M. Özcan'ın insanın neliğine dair kategorik yaklaşımı bu alandaki önemli çalışmalardır. Bütün bu çalışmalar M. Scheler'in insanın anlamına dair yaptığı çalışmayla başlamıştı. Ancak daha öncesinde Aydınlanma ve sonrası genişleyen, akıl ve insan üzerine çalışmalar, özellikle Kant, Hegel, Marx ve Nietzsche gibi düşünürlerce farklı yönlerden ele alınmıştı. Bu kategorik/farklı yaklaşımlar içinde kuşkusuz klasik bütüncül yaklaşımın temel unsurları olmakla beraber, özellikle son yapılan çalışmalarda, artık insanın metafizikle ilgisinin kurulduğu ruh kavramının çok az kullanıldığı ya da önemsizleştiğini görmekteyiz. İnsan ve insanlık kavramlarının külli ve cüzi/tikel/tekil anlamlarda kullanımı üzerine ortaya koyulan ayrıştırıcı bazen de indirgeyici söylemler, tek tek örnekler üzerinden çözüm üretmekle birlikte, bütüncül anlamda 'insan nedir?' sorusuna tatmin edici bir cevap vermeyi de zorlaştırmaktadır. Mengüşoğlu'nun tanımı yine bu kategorik yaklaşımlar içinde bütüncü yaklaşımı en çok andıran tanımdır. Nitekim onun tanımı da Scheler'in bakış açısının bir devamı ve kısmi olarak da gelişmiş/genişlemiş bir hali olarak görülebilir. Mengüşoğlu, insanı bilen, yapıp eden, değer sahibi, önceden görüp belirleyebilen, özgür olan, tarihsel, kendini ideleştirebilen, seven, çalışan eğiten ve eğitilen, medeniyet ve sanatın yaratıcısı olan, konuşan biyo-psişik bir varlık olarak sınıflandırmaktadır. ${ }^{28}$ Tüm sayılan bu özellikler ve buna benzer olan diğer özellikleri onun biyolojik/maddi yaşam ve psişik/ruhî bir varlık olduğunu göstermektedir. Benzer bir yaklaşımı Scheler'de

24 Ali Durusoy, “İbn Sînâ Felsefesi’nde İnsan”, içinde Doğu'dan Batıya Düşüncenin Serüveni, ed. Abdullah Kahraman, 1. bs, c. 5 (İstanbul: İnsan Yayınları, 2015), 974-75.

25 Aristoteles, Politika, çev. Mete Tunçay (İstanbul: Remzi Kitabevi, 1993), 9.

26 İbn Sînâ, Kitâbu'ş-Şifa (Metafizik), çev. Ekrem Demirli ve Ömer Türker (İstanbul: Litera Yayinc1lik, 2004), 197, 209.

27 Ahmet Koç, “İhvân-1 Safâ ve Eğitim”, içinde Doğu'dan Batıya Düşüncenin Serüveni, ed. İsmail Çalışkan, 1. bs, c. 6 (İstanbul: İnsan Yayınları, 2015), 297, 302.

28 Takiyyüddin Mengüşoğlu, İnsan Felsefesi (İstanbul: Doğu Batı Yayınları, 2017), 19-20. 
de görmekteyiz. $\mathrm{O}$ da insanın biyo-psişik bir varlık olduğunu ancak sahip olduğu geist/ruh sayesinde ben bilincine ulaşabileceğini, ama bununla beraber diğer canlılarla belli ortak özelliklere sahip olduğunu da kabul etmektedir. Descartes bağlamında klasik akıl ve ruh, ruh ve madde ayrımına dayanan düalist bakış açısını da eleştirmektedir. Ancak Scheler'in içgüdü, bellek ve zekâ bağlamında insan, hayvanlar ve bitkiler arasındaki ilişkinin zaman zaman klasik İslam düşüncesindeki nefs anlayışını anımsattığı da görülmektedir. O bu ilişkiyi basit bir ilişki olarak nitelendirirken biyo-pisişik özelliğin hem hayvan hem de insanda olduğunu ama insanı farklılaştıran şeyin bizatihi geist/ruh/tin olduğunu söylemektedir. Nitekim insandaki bu geist ona has bir özgürlük, seçme ve zekâ imkânı vermiştir. İnsan, 'insan olmaklığı'nı bu şekilde sağlamıştır. ${ }^{29}$ İ. Kuçuradi insana gnoseolojik bakmanın belli çıkmazları olduğunu ifade eder. Yani varolanı obje, insanı da sadece bir süje olarak kabul edip, onun varlık bağlantılarını gerçeklik düzeyinden kopardığımızda 'insan nedir?' sorusuna tam bir cevap verme imkânımız da yoktur. ${ }^{30} \mathrm{Bu}$ nedenle Kuçuradi meseleye kategorik bir yaklaşım sergilemektedir. Kuçuradi, tarihte insanlık kavramıyla özdeşleşen yaratıcı insana vurgu yapan ve bu insanı 'benim' diyen olarak tanımlayan ${ }^{31}$ Nietzsche'nin insan anlayışı bağlamında düşünürün üçlü sınıflamasına özel vurgu yapmaktadır. Bu sınıflamaya göre Nietzsche insanı sürü, hür ve trajik olarak üç sınıfa ayırmaktadır. Sürü insanın, sıradan insan türünü ifade için kullanıldığını söyleyen düşünür, hür insanın kısmi olarak bu sıradanlıktan kurtulduğunu ancak trajik insanın özgürlük aşamasını geçmiş iradi olarak hayır demesini bilen, ama her türlü olumsuzluklara rağmen yaşamı da seven insan olarak nitelemektedir. O gerçekliği olduğu gibi görüp kabul eden bir insandır. ${ }^{32}$ İnsanın ayrıştırıcı özelliği, onun fenomenlerin bilgisine sahip olmasıdır. O ahlaklı, bilgili ve bilinç sahibi bir varlıktır. ${ }^{33}$ Konuya tür olarak 'insan nedir?' sorusu üzerinden yaklaşan Kuçuradi, insanın doğal yapısına dair kavramsal bilgimizi oluşturmaya çalışır. Ona göre bu bilgimizi oluşturan unsurlar insanî etkinliklerdir. Bunlar bilme, değerlendirme, eylemde bulunma, çalışma ve yaratma gibi, insanî imkânları ortaya koyan şeylerdir. İnsanî olma vasfını da bu etkinlikler bize sağlamaktadır. ${ }^{34}$ Zira insan söz konusu değerleri belli bir amaca yönelik, kendisi bir medeniyet olarak inşa etmektedir. Bilimi, sanatı, hukuku, etiği bu yapının içinde, insanî vasıf ve ayırıcı özellik olarak diğer varlıklardan onu farklı kılan hususlar olarak kabul etmektedir.

29 Max Scheler, Insanın Kozmos 'taki Yeri, çev. Tomris Mengüşoğlu (İstanbul: Yaprak Yayınları, 1988), 12, 15-16, 39-40.

30 İonna Kuçuradi, İnsan ve Değerleri (Ankara: Türkiye Felsefe Kurumu, 2013), 21.

31 Kuçuradi, 22.

32 Kuçuradi, Nietzsche ve İnsan, 45, 81, 102.

33 İonna Kuçuradi, Etik (Ankara: Türkiye Felsefe Kurumu, 2006), 53-54.

34 Kuçuradi, 170-71. 
Düşünür gnosiolojik açıdan bakmanın bir çıkmaz olduğunu, insana bakışın çağa ve ortaya çıkan koşullara göre değişkenlik gösterdiğini ifade eder. Çağa yön veren yaratıcı kişiler insan realitesini bu koşullar altında değerlendirmektedirler. Düşünür bu değişkenlik durumunun kısır bir çember olmadığını ifade eder. ${ }^{35}$ Ancak etik açıdan insanın değerleri bağlamında somut bir öneri getirmeksizin değişkenlik durumunu ifade ederek bırakmıştır. İnsana kategorik yaklaşıma dair en dikkat çekici yaklaşım, Özcan'ın İnsanın Neliği Üzerini Bir Soruşturma adlı eserinde ortaya konmuştur. Düşünür, Scheler'le başlayıp ülkemizde Mengüşoğlu ve Kuçuradi ile devam eden antropolojik yaklaşıma, kategorik üçlü bir sınıflamayla çözüm üretmeye çalışmıştır. Düşünce tarihinde ‘insan nedir?' sorusuna verilen cevapları bir araya topladığımızda bu üçlü ayrımı kısmi ya da külli olarak her filozofta görmek mümkündür. Bu ayrıma göre insan, a) birey, sürü (tekil) veya sıradan insan; b) model insan anlamında yaratıcı ve üstün insan; c) genel anlamda tür veya kavram olarak insan olarak sınıflandırılmıştır. ${ }^{36}$ Düşünüre göre, özellik ve içerik olarak zaman zaman birbiri içine geçmekle birlikte, bizim de kabul ettiğimiz, yani akıl, irade ve ruh sahibi, özgür ve yapabilen bir varlık olarak insan tanımı, yeterli değil ve bazı sorunlar barındırmaktadır. Özcan, söz konusu bu özelliklerin hepsinin bir anda gerçekleşme imkânı olmadığını, özgür, akli ya da ahlaki bireyin, tek tek her bir birey için mümkün olmadığın $1{ }^{37}$ ifade ederek böyle bir sınıflandırmayı yaptığını söyler. Düşünce tarihi boyunca insan ve eylemlerini ele aldığımızda sınıflandırma bakımından konuya kategorik bağlamda yaklaşmanın, ortaya konulan düşünceleri ve ürünleri sınıflandırmak bakımından yararlı olabileceğini düşünüyoruz. Ancak böyle bir kategorizasyonun bütüncül bakış açısının bize sağladığı ve insan olmaklık durumuna dair metafizik bir bakışın ortaya çıkmasını sağlayacak olan unsurları da anlamsızlaştıracağını düşünüyoruz. Yine aynı durumun düşünürler bağlamında ele aldığında indirgemeci bir tavra evrilmeyi doğuracaktır. Bu durum, artık tarihsel ve düşünsel bir değer olarak, Platon ve Aristo başta olmak üzere, pek çok önemli şahsiyetin bizatihi kendilerini konumlandırmadıkları bir kategorizasyon içinde olmaları anlamına gelmektedir. Kuşkusuz evrim anlayışı ve buna bağlı yeni bilimsel tavır, klasik kabulleri ciddi sarsmış hatta bazılarına göre tamamen yok etmiştir; ancak bunun tam böyle olmadığını insan olmaklık durumunun anlam dünyasının inşa edilmesinin yine canlılığın en önemli esası olan akıl ve ruh üzerinden inşa edilmesi gerektiğini düşünüyoruz. Öğrenme eyleminin bu kriter üzerinden inşa edilmediğinde, Aydınlanma sonrası yaşadığımız insan ve eğitim ilişkisindeki kırılmanın ortaya çıkardığı durumu tam olarak anlamamız mümkün değildir.

35 Kuçuradi, İnsan ve Değerleri, 98-99, 102, 106.

36 Özcan, Insan Felsefesi, 27.

37 Özcan, Insan Felsefesi, 14. 


\section{2. Öğrenme eylemi ve İnsan}

‘İnsan nedir?’ sorusuna verilen farklı cevaplara rağmen, bütüncül yaklaşımın bize imlediği, onun akıl ve ruh sahibi, madde ve formdan oluşan, iradî, ahlakî ve medeni bir varlık olduğudur. Kavram olarak insanın içerdiği tüm özellikler, bilkuvve olarak tek tek tüm insanları kapsamaktadır. Yani her bir insan teki potansiyel olarak bu özellikleri gerçekleştirebilme ve 'insan olmaklık' durumunu başarabilme şansına sahiptir. Bu imkân yaratılıştan ya da zekânın ona sağladığı imkânlardan kaynaklanacağı gibi, eğitim ve öğretimin burada olmazsa olmaz bir önemi vardır. Bizatihi insan olmak demek, aslında öğrenebilen bir varlık olmak demekle aynı şeydir. Daha önce de işaret ettiğimiz gibi, Âdem olma durumu, aslında insan olmanın tüm imkânlarını da bize sunan bir örnek olması bakımından çok önemlidir. ${ }^{38}$ İnsana verilen aklın ve iradenin, Tanrısal özle ve görevle birleştiğinde, neleri gerçekleştirip gerçekleştiremediğinin cevabı insanlık tarihinde yatmaktadır. Ortaya konulan medeniyet, toplumları şekillendiren üstün/bilge/hikmet sahibi insanların şahitliği bunu bize göstermektedir. Ancak 'insan olmaklık' ya da öğrenebilen bir varlık olarak insanın bilinç düzeyinin nelere kadir olduğunun bilinmesi ve her bir insan tekinin aslında bu imkâna sahip olması anlamında, var olan problemlere ya da gelecekteki problemlere çözüm odaklı yaklaşmamızda yadsınamaz bir katkısı olacaktır.

Tabiatta en zayıf varlıklardan biri olarak doğan insan, bilgi ile zamanla ona hakim olmayı ve diğer varlıklara da hükmetmeyi öğrenmiştir. Aslında insanın bu dünyada kazanmış olduğu olumlu/olumsuz her şeyin temelinde öğrenebilme imkânının ona verdiği epistemik kazanımlar vardır. Bundan dolayıdır ki, felsefenin en önemli alanlarından birisi epistemolojidir. Ancak epistemolojinin pratik alanda hayatın içindeki yüzü, insanı her an şekillendiren eğitim olgusu ve faaliyetidir. Zira insan eğitimle kendini tanımakta, zayıflıklarının ya da farklılıklarının bilincine vararak tercih yapabilmektedir; bir anlamda eğitimle kendini daha da özgür k1lmaktadır. ${ }^{39}$ Özgür ve sorumlu bir varlık olarak, hayatının her anında bununla yüzleşen ve ona göre hayatı kurgulayan bir canlıdır insan.

Eğitim/Öğrenme faaliyetinin en önemli yanı, bireyin kendi varlık bilincine varması ve yapabileceklerini keşfetmesidir. Sokrates'in bir öğretici ve rol model olarak gençler üzerindeki etkisini, öğrenme ve öğretme eyleminin gücünü göstermesi bakımından başlı başına ontik ve epistemik bir örnek olarak alabiliriz. Onun, gençlere neyi, nasıl, niçin gibi soruları sorarak diyaloglar şeklinde ortaya koyduğu eğitim faaliyetinin düşünce tarihindeki adı doğurtmadır. Bir tür tümevarım gibi tikelden

38 el-Hicr, 15/26, 15/28-29; er-Rahman, 55/4; el-Araf, 7/11.

39 Mark Twain, İnsan Nedir?, çev. Esra Şimşek (İstanbul: Turkuaz Kitap, 2020), 10. 
tümele, özelden genele ulaşarak, bireyin kendinden genel hakikate ulaşmasını bu türden sorgulamalarla yapmaya çalışıyordu. ${ }^{40}$ Adeta kendisi bir ebe, muhatabı olan insanlar ise her an doğurmaya hazır gebeler gibiydi. Muhataplar bilgi bakımından neye gebe ise, o bu doğurtma sanatıyla ortaya çıkmasını sağlıyordu. ${ }^{41}$ Böylece bireyin kendini bulması, potansiyelini keşfetmesi ve var olan hakikatle yüzleşmesini sağlıyordu. O eleştirdiği Sofistler gibi öğrencilere hazır kalıplar vermek yerine onları gerçeği bulmaya teşvik ediyordu. ${ }^{42}$ Nitekim talebesi olan Platon da bilgiyi idealar teorisi bağlamında bir hatırlama olarak tanımlamıştır. Ancak Platon ortaya koyduğu etik ve devlet görüşleriyle insani gelişimi etik bağlamda bir tür eğitim faaliyetine sokmuş, devleti de tüm unsurlarıyla iyi eğitilmiş vatandaşlarla ayakta tutmaya çalışmıştır. Devleti, toplumu ve insanı aynı ontik ve metafizik açıyla yorumlayarak ortaya konulan faaliyetleri bu şekilde anlamlandırmıştır. İdealist bakış açısının kurucu filozofu Platon, Devlet eserinde toplumu oluşturan unsurları sınıflandırıp onların görev bilincini inşa edecek ve geleceği teminat altına alacak şeyin eğitimden geçtiğini göstermiştir. Özellikle asker ve yönetici olacak çocukların sıkı bir düşünsel ve bedensel eğitimden geçmesini zorunlu kılmıştı. Yönetici olacakların toplumu ayakta tutacak zihinsel kapasiteye ve metafizik öngörüye de hakim olması ayrıca önemlidir. Eğitimi bir yetiştirme faaliyeti olarak tanımlayan Platon, beden için idmanın, ruh için de müziğin yetişmenin ilk safhası olduğunu ifade eder. ${ }^{43}$ Ayrıca matematik ve astronominin eğitim açısından önemli olduğuna vurgu yapan düşünür çocukların, askerlerin/bekçilerin ve idarecilerin eğitiminin önemli olduğuna vurgu yapar. ${ }^{44}$ Ancak bilginin neliği hususunda özellikle Platon'un mağara alegorisi bilgiye ve buna bağlı eğitime bakış açısını da aslında yansıtmaktadır. Mağara, insanın eğitimle aydınlanmamış halini temsil etmektedir. ${ }^{45}$ İdealar teorisinin bir sonucu olarak, bir hatırlama süreci olan bilgiyi eğitimle insanın bu dünyadaki gelişmesine de imkân sağlayacak en önemli unsur olarak görmektedir. Burada ruh iyi ideasıyla yüzleşebilen metafizik bir unsurdur. Eğitim aslında kör gözlere görme gücü vermek gibi, bilgiden yoksun olan ruha da bilgiyi vermektir. Her ruh için öğrenme imkânı vardır. Eğitim, ruhun gücünü iyi ideasına çevirmesi, sahip

40 Mehmet Zeki Aydın, "Sokrates'in Doğurtma (Buldurma) Yöntemi”, içinde Doğudan Batıya Düşüncenin Serüveni, ed. Celal Türer ve Hakan Olgun, 1. bs, c. 2 (İstanbul: İnsan Yayınları, 2015), 143.

41 Platon, “Theaitetos”, içinde Diyaloglar, çev. Macit Gökberk (İstanbul: Remzi Kitabevi, 2010), 504 (184b).

42 Bayram Ali Çetinkaya, Felsefe Tarihi Antik Doğu'dan Modern Batı'ya (Ankara: Nobel Yayıncılık, 2017), 106-7.

43 Platon, Devlet, 67 (376d-e).

44 Platon, 207, 211 (523a, 526d).

45 Platon, 199 (514a). 
olduğu gücü keşfetmesidir. ${ }^{46}$ Platon' da bilme eylemi bizatihi insan olmanın ontik bir sonucudur.

Antik çağın diğer büyük düşünürü Aristo ise eğitim ve insan ilişkisine daha rasyonel bir yönden yaklaşmıştır. Eğitimi özellikle alışkanlık kavramı üzerinden izah eden düşünür, istendik davranışların kalıcılığını, eğitimin sayesindeki tekrarla mümkün olduğunu vurgular. Alışkanlık insanın iyi erdemlerini devamlı kılması için kullandığ bir unsurdur. Bazen formel ve sözlü eğitimin yeterli olmadığ durumlarda, alışkanlıklar eğitime pratik bir katk1 vermektedir. Aristo'nun eğitim ve alışkanlıkla kazanılanın korunması ve toplumda kalıcı değişiklikleri yaratabilmesi için, söz konusu kazanımların yasaların güvencesi altında olması gerektiğine vurgu yapar. ${ }^{47}$ Bireyin iyi bir yaşama ulaşması, eğitim, erdem ve yeteneğine bağlıdır. ${ }^{48} \mathrm{O}$ da hocası Platon gibi konuya bütüncü1/küllî bir bakış açısıyla yaklaşmıştır.

Antik dönemde karşımıza çıkan, eğitilebilir bir varlık olan ve eğitim faaliyetinin hem öznesi hem de nesnesi bağlamında ele aldığımız insanın merkezi konumu, dini bakış açısıyla Ortaçağ Hıristiyan ve İslam dünyasında devam etmiştir. Ancak teolojik bakış açısının imlediği kutsalla ilişki kuran insan, ruhi bağlamda da artık daha özel ve ontik anlamda daha kuvvetli bir noktaya gelmiştir. Hıristiyanlık ve İslam'la beraber insan bizatihi Tanrı tarafından bilgiyle kuşatılmış ve bu dünyaya hükümran olması için gönderilmiş bir insandır. Ancak bu durum tabiatçı/natüralist bakış açısının gelişmeye başladığı Rönesans ve sonrasında önemli kırılmalara uğramıştır. Özellikle, ilerlemeci, egzistansiyalist, pragmatist ve empirist bakış açılarının ortaya koyduğu birikim klasik bakış açısının zayıflamasına ve insanın ontik önemi üzerinden inşa edilen metafizik anlamın zayıflamasına neden olmuştur. Tüm bu anlayış da eğitim faaliyetlerinin şeklini ve yapısını derinden etkilemiştir.

Eğitimin insanın doğumundan ölümüne değin süren, istenen bilgi ve beceri, tutum ve değerleri kazanması gereken bir süreç olduğu genel bir kabuldür. Ancak bu kabulün merkezinde olan insanın yapısına dair, ontik, epistemik ve metafizik bakış yapılan faaliyetin anlamını da doğrudan etkilemektedir. Düşünce tarihi boyunca, Aydınlanma sonrası ve özellikle antropolojik yaklaşımlar haricinde, insanın yapısına dair düalist bakış açısının imlediği ontik ve metafizik bakış açıları öğrenme eyleminin anlam dünyasını da şekillendirmiştir. Nitekim antikçağda hakim olan akıl ve ruh sahibi varlık olan insanın durumu, ortaçağ boyunca sudûrcu anlayışı savunan

46 Platon, 203-204 (518b-e); Muharrem Hafiz, "Platon ve Siyâset Felsefesi", içinde Doğudan Battya Düşüncenin Serüveni, ed. Celal Türer ve Hakan Olgun, 1. bs, c. 2 (İstanbul: İnsan Yayınları, 2015), 174.

47 Aristoteles, Nikomakhos'a Etik, 217-220 (1179a5-35, 1180a1-15).

Aristoteles, Politika, 92. 
Müslüman ve Hiristiyan düşünürlerce korunmuştur. Eğitim ve insan ilişkisinde ona metafizik anlam kazandıran en önemli şey, sudûrun ikinci ve üçüncü hipostazları olan zekâ/akıl ve ruhtur. Mümkünler aleminde insanın diğer varlıklardan farklı olarak hem akla hem de ruha sahip olmasıdır. Nefs teorisiyle izah edilen üçlü ruh taksiminde insan bitkisel ve hayvani özellikleriyle diğer yaratılmışlarla ortak olan bir yapıya sahipken, insani olan nefsle, bilinçli bir eğitimin hem öznesi olmakta, hem de metafizik bir özle bağlantı kurabilecek bir hakikatle yüzleşmektedir.

İslam düşüncesine baktığımızda, insan ve eğitim arasındaki ilişki antik dönemin daha gelişmiş bir versiyonudur. İnsanın anlamına dair metafizik öze katkı sağlayan dini/teolojik bakış açısı, özellikle dini eğitimde insana ben bilinci vermek üzerinden inşa edilmiştir. İnsanın bir beşer olarak yaratıcı ile kurduğu bağ onun eğitim faaliyetinin de ana karakteristiğini yansıtmaktadır. Dualist ve sudûrcu bakış açısının hakim olduğu İslam düşüncesinde insana yüklemlenen anlam eğitim sayesinde kendine yaşam alanı bulmaktadır. Antik dünyadaki Lise ve Akademi'nin bir anlamda benzeri olan Nizamiye medreseleri ve Bağdat okulu ${ }^{49}$ ve Beytü'l Hikme gibi merkezlerdeki çalışmalar, eğitim ve düşüncenin bir toplumu şekillendirme açısından ne denli önemli olduğunun göstergesidir. Mesala Fârâbî’ye göre insan, akıl ve ruh sahibi olarak fazıl bir şehirde kendini gerçekleştirebilir. Fazıl/ideal şehrin yönetimini üstlenen filozofun sahip olması gereken en önemli şartların başında bilgi edinmeyi, öğrenmeyi sevmesi ve bunun zahmetlerine de katlanmayı bilmesidir. ${ }^{50}$ Fârâbî’nin şehrinde eğitim ilerlemenin en etkin yoludur. Öğretim ve eğitimle nazari erdemleri insanlara ve toplumlara/şehirlere öğretebiliriz. ${ }^{51}$ Eğitim bireylere yeniden insan olmayı ve mutluluğa ulaşmayı sağlayacaktır. Düşünür, insanın bireysel gelişiminde başkalarıyla olan tartışmalarında kendini hazır hissedebilmesi için, kendini eğitmesi gerektiğini vurgulamıştır. Ona göre eğitim bir tür sanat gibidir. ${ }^{52}$

Fârâbî öğretim faaliyetinin iki şeyden meydana geldiğini ifade eder. Bunlardan birincisi okunan şeyi anlatma ve ona dair düşüncenin nefsimize yerleşmesi; ikincisi kavranan/öğrenilen ve manası nefsimize yerleşmiş olanın kabul ve tasdik edilmesidir. Öğrenim faaliyetinde aklın önemine vurgu yapan düşünür bir şeyi kavratmak/ öğretmek için ya mahiyetinin akılca kavranmasına çalışılması gerektiğini ya da ona

49 Ahmet Kayacık, "Bağdad Okulu”, içinde Doğudan Batıya Düşüncenin Serüveni, ed. Abdullah Kahraman, 1. bs, c. 5 (İstanbul: İnsan Yayınları, 2015), 272.

50 Fârâbî, İdeal Devlet, 105.

51 Ebu Nasr el-Fârâbî, Farabî'nin Üç Eseri: Mutluluğu Kazanma (Tahsilu's-Sa'ade) Eflatun Felsefesi ve Aristo Felsefesi, çev. Hüseyin Atay (Ankara: Ankara Üniversitesi İlahiyat Fakültesi Yayınları, 1974), 38.

52 Fârâbî, Farabî'nin Üç Eseri, 110-112. 
uygun örnekle desteklenmesi gerektiğini söyler. ${ }^{53}$ Eğitimin mutluluğa ulaşmada ve insana istenilen bilginin aktarılmasında bir araç olduğundan bahsederek, bunun nasıl olacağı hususunda insanları ikna etmeye çalışır. Benzer düşünceler, özellikle de eğitimin insanın ruhî ve bedenî olarak gelişmesi, erdemli olması, ben idrakine varması için bir vasıta olduğu hususu hemen hemen çoğu İslam filozofunda karşımıza çıkmaktadır. İnsanı yaratıp, halife kılan Tanrı, alegorik olarak kendini ilk öğretmen kılarken, ilk öğrenci olan insanoğlunun tabiattaki gelişiminin ana öğesi ise kesinlikle eğitimdir. ${ }^{54}$ Fitrat üzere doğan insan huy ve eğilimlerini ancak eğitim ve iyi alışkanlık sayesinde düzeltmekte ve ilerleyebilmektedir. ${ }^{55}$ İbn Sînâ insanın toplumsal bir canlı olduğuna vurgu yaparak, kendi kendine yetememesinden dolayı insanlarla beraber yaşaması ve toplum kurallarına uymayı öğrenmesi gerektiğine vurgu yapar. Mutluluğun toplumun tüm bireylerinin üzerine düşeni yapmasiyla mümkün olduğunu düşünen İbn Sînâ, ailede annenin çocuk eğitim ve terbiyesinde çok önemli olduğuna işaret eder. ${ }^{56}$ İslam dünyasında özellikle yaygın eğitim ve içeriği hakkında, dinî eğitim politikalarında Gazzâlî'nin (ö. 1111) İhyâ ve Mîzân 'ül Amel'deki yaklaşımı oldukça önemlidir. ${ }^{57}$ Gazzâlî’nin bakış açısı yaygın dini eğitim anlayışını uzun süre etkilemiştir. İslam dünyasındaki metafizik anlamın yoğun olduğu bakış açısı uygulama imkânı artık mümkün olmamakla birlikte tarih boyunca zayıfta olsa günümüze kadar varlığını sürdürmüştür. Bu nedenle benzer örnekleri de çoğaltmak mümkündür.

\section{Eğitim ve Metafizik Anlam}

Aristo Metafizik adlı eserinde metafiziği var olmak bakımından var olmanın ilimi/bilimi olarak tarif eder. ${ }^{58}$ Ona göre insan doğal olarak bilmek ister. ${ }^{59}$ Çünkü eğitim faaliyeti insanoğlunun ilk bilinçli faaliyetidir. Bu bilincin içinde, özgürlük, iradî bir ben idraki ve ahlaki sonuçları olan sorumluluk bilinci vardır. Eğitilebilir bir varlık olarak insanın, öğrenme ve öğretme eyleminin anlamı, onu inşa ettiği metafizik zemin/zihin çok önemlidir. Mümkün varlıklar içinde, Âdem olmaklık

53 Fârâbî, Farabî'nin Üç Eseri, 53.

54 Koç, "İhvân-1 Safâ ve Eğitim”, 297.

55 Murat Demirkol, “13. Yüzyılın Bilge ve Kelamcı Filozofu Nasireddin Tûsi”, içinde İslam Felsefesi El Kitabı, ed. Bayram Ali Çetinkaya (Ankara: Grafiker Yayınları, 2017), 297.

56 Durusoy, “İbn Sînâ Felsefesi’nde İnsan”, 978.

57 Avner Giladi, "Islamic Educational Theories in the Middle Ages: Some Methodological Notes with Special Reference to al-Ghazali”, British Society of Middle Eastern Studies 14, sy 1 (1987): 6 .

58 Aristoteles, Metafizik, çev. Ahmet Arslan (İstanbul: Sosyal Yayınları, 2010), 196 (1004b4-16).

59 Aristoteles, 75 (980a20). 
bakımından öğrenme eyleminin ilk muhatab1, aklı olması sayesinde öğrenebilen, kendini geliştirebilen, içgüdüsel olmayan, iradî olan, ruhsal yapısı ile metafiziksel bir öze sahip ve onunla ilişki kurabilen bir varlık olan insandır. Nitekim pratik aklıyla bu alemi, teorik aklıyla metafizik gerçekliği algılayabilen insanın, bu hakikati zamanla unuttuğunu ve anlamdan uzaklaştığını görmekteyiz. Yaşanan sürecin daha iyi anlaşılması için antik dünyadan Rönesans'a kadar gelen dönemde hem Yunan, hem de Huristiyan ve İslam düşüncesinde kendine yer bulan üçlü ruh/ nefs teorisinin tekrar hatırlanmasında fayda vardır. Zira eğitim faaliyetinin öznesi ve nesnesi olan insanın eğitim ve metafizik bağlamda tespiti, bütüncül bir bakış açısının ve tarihsel sürecin iyi bilinmesine bağlıdır. Dini düşüncenin hakim olduğu ortaçağ düşüncesinde, bu anlam yoğun teolojik ve teleolojik bakışla beraber inşa edilmiştir. Ancak yeniçağın getirdiği, özellikle rasyonel ve bilimci bakış açısı hem teleolojik hem de metafizik bakışın ve anlamın ciddi bir zarar görmesine neden olmuştur. Ortaya çıkan ciddi kazanımlara rağmen, insanın anlamına dair bakış açısının ciddi bir değişime uğradığını ve çağdaş dünya bağlamında önemli bir bozulmanın/değişmenin söz konusu olduğu görülmektedir. Bu bozulma ve değişimin pek çok dinamiği olduğu gibi bizim için asıl önemli olan insanın en önemli gelişme unsuru olan eğitimin metafizikle olan ilişkisi bağlamındaki gerilemeye dair olan süreçtir. İnsanın yeniden bir anlam dünyasını bağımsız, ilkeli ve ahlaki bakımdan inşa edebilmesi, klasik bağlamda varlığı sürdüren metafizik zihniyetin yeniden ele alınması ve eğitim faaliyetlerinde, özne olan zihinlere onunla tanışma imkânı verilmesine bağlıdır.

Metafiziğin kuşkusuz en önemli yanı varlığı anlamamızı sağlayan yönüdür. Varlık olarak insan tarih boyunca bilgi ile olan yücelmesinde zaman zaman Tanrısal güce tam bir teslimiyet zaman zaman da kendisinin Tanrısallaştığı bir ontik düzlemde kendine yer edinmiştir. Özellikle Aydınlanma sonrası hızla değişen dünyamızda, insanın daha rasyonel ve bilimsel bakış açısı, doğa ile mücadelesindeki kazanımları, kadim dünyanın teolojik ve klasik metafizik bakış açılarının ciddi bir şekilde zayıflamasına neden olmuştur. Bu nedenledir ki, günümüz dünyasında insan, eğitimi bilgiye sahip olmak için bir araç kılarken, klasik bağlamdaki eudomonist/ mutlulukçu anlayış yerine daha narsist ve egoist amaçlar ortaya koymuştur. İdeolojik ve indirgemeci teolojik ve felsefi bakışlar da bu gidişi hızlandırmıştır. Bu nedenle insan olmaklık eylem ve erdemini göstermeyen, eğitimli ama ahlaklı ve özgeci olmayan, kendiyle ve ontik varlığıyla kavga eden çağdaş bir dünya/birey ve eğitim camiası ortaya çıkmıştır. Bu nedenle eğitim ve metafizik anlam ilişkisi ve köprüsü yeniden kurulmalı ya da hatırlanmalıdır. Nihayetinde kadim düşüncede var olan, ancak sonradan unutulmaya yüz tutan metafizik bakış açısı yeniden anlam kazanacaktır. Böylelikle, insana dair anlam arayışı, antik çağın insanı merkeze alan 
"Nosce te İpsum" (kendini bil) mottosu, ${ }^{60}$ Aydınlanmayı karakterize eden "sapere aude" (aklını kullanma cesaretini göster) ${ }^{61}$ mottosu ile kullanıldığında, yeniden düşünce dünyamızda metafiziksel bir bakış canlanacaktır.

İnsan, bilinçli bir eğitim faaliyetinin hem öznesi hem de nesnesi olan tek varlıktır. O düşünce tarihi boyunca çoğunlukla akıl-ruh ve ruh-beden dualiteleri içeresinde açıklanmaya çalışılmıştır. Dini literatürümüzde Hz. Âdem, insan olmaklık bakımından eğitilebilir varlığa verilebilecek en iyi örnektir. $\mathrm{O}$ ilk insan ve ilk öğrencidir. Yaratıcının bizatihi ruhundan üflediğ $i^{62}$, ilk yaşayan varlıktır. ${ }^{63}$ İnsana öğretilen eşyanın isimleri, bilginin ilk örneği, Tanrısal gücün ilk inkişafı, metafiziğin mümkün bedendeki ilk tezahürüdür. Yapılan secde temsili olarak Âdeme, metafiziksel olarak ise verilen hikmete ve bizatihi yaratıcının kendisinedir. Âdem örneği ontik ve epistemik açıdan dini/klasik literatürümüzde insan olmaklık durumunun ne anlama geldiğinin en iyi örneğidir.

Eğitim faaliyetinin en önemli yanı, nesnesi olan bireye zihinsel özgürlük imkanı tanıması, ahlaki varlık olarak kendi varlığının bilincine ve sorumluluğunun farkına varmasını sağlamasıdır. Günümüzde artık devasa bir sektör olan eğitimin sürdürülebilir ve insani değerlerle barışık bir çıktı oluşturabilmesi için, söz konusu değer sisteminin tüm eğitim kurumlarınca ve siyasi erk tarafından ortak kararlarca belirlenmesi gerekmektedir. Ancak ideolojik ve teolojik angajmanlar, günümüz dünyasında eğitim artık sadece bilgi aktarımı olarak değil, kendi düşünce sisteminin geleceği olan bireyleri yetiştirmek için bir araç olarak görülmekte ve çoğunlukla bilinçsiz ve metafizikten uzak bir faaliyet olarak yürütülmektedir. Bu bakış açısı özellikle din ve sosyal alanlardaki eğitimlerde ciddi sıkıntılara yol açmaktadır. Konformist ve ideolojik bakış açıları, eğitimin ontik boyutunun yok olmasına, araçsallaştırılmasına ve hatta bizatihi insanlığı tehdit eden bir silah haline gelmesine neden olmaktadır. Bu nedenle insan olmanın gerçek anlamı olan metafizik bağlamın eğitimle olan ilişkisi yeniden tesis edilmelidir.

Klasik üçlü ruh/nefs ayrımında olduğu gibi insanın yapı olarak hayvan ve bitkiler gibi diğer varlıklarla ortaklaştığı özellikleri bulunmaktadır. Diğer taraftan insanî olarak nitelenen kısmı ise daha çok, akıl, irade ve sorumluluk kavramlarıyla donatılmış ve ahlaki bir özne kılınmıştır. İnsanın bu yanı aynı zamanda ruhun ölümsüz tarafını da temsil eder. Ruhun bu kısmı, İnsanın metafizikle ilişki kurmasını

60 Bu motto Apollon adına kurulan Delphi tapınağının kapısına nakşedilmiş bir deyiştir.

61 Immanuel Kant, “Aydınlanma Nedir? Sorusuna Yanıt (1784)”, çev. Nejat Bozkurt, Toplumbilim Aydınlanma Özel Sayısı, sy 11 (Temmuz 2000): 17.

62 El-Hicr, 15/29.

63 Kitabı Mukaddes, Yaratılış.1:2. 
ya da bizatihi onu keşfetmesini ve bu dünyadaki ontik ve epistemik faaliyetleri anlamlı bir şekilde yapabilmesi sağlayan kısmıdır. İnsan nedir? sorusuna verilen cevapların sonuçlarında onun akıllı, ahlaki bir varlık olması, Platon ve Aristo'da ifade edildiği gibi ruhun akla ve erdeme uygun davranması durumu, ${ }^{64}$ metafizik boyutun canlı olduğunun göstergesidir. Önemli olan, Platoncu bir bakışla ifade edilirse, var olanın yeniden keşfedilmesi ve onun kıymetinin bilinmesidir. İnsan akı1 sahibidir, özgürdür, özgürlüğünü kullandığı ölçüde sorumludur. İradesi gereği doğru ve yanlış yapabilme, sanat ve tekniğin yaratıcısı olabilme imkânına sahiptir. Bu özelliklerin insan olmaklık eylemiyle birleştiğinde bizi ulaştıracağı nokta, insanın ruhi/metafizik bir özün, mümkünler alemindeki bir temsilcisi olmasıdır. Onun yaradılışına uygun görevini bilmesi ve bunu keşfetmesi gerekir. Nitekim insan olmaklık durumu/işi sadece insana bahşedilmiştir. ${ }^{65}$ İnsan eğitimle bu hakikati işleyerek daha ileri götürebilecek, ruhun gücünü iyiden yana çevirmeyi eğitim faaliyetiyle sağlayacaktır. İnsanın bedensel güçleri çalışmayla gelişebilir ancak, düşünme gücü eğitimle ileri gider, hiçbir zaman yok olmaz zira onda Tanrısal bir yan vardir. ${ }^{66}$

Öğrenme eyleminin epistemik süreci insan hayatını doğrudan etkilemektedir. İstendik sonuçlara ulaşmak ve bunu bilinçli bir anlam dünyasına dönüştürmek ancak insan için mümkün olan bir şeydir. Önemli bir öğrenme eylemi olan felsefenin de yapmaya çalıştığı şey aslında insanı sadece bilen değil, bilinçli olan, düşünen, bilgiler arasında bağlantı kurabilen ${ }^{67}$ ve hayatını buna göre düzenleyebilen biri yapmaya çabalamasıdır. Ortaya çıkan birikim ve bunun sonuçları bilgi birikiminin ve buna bağlı oluşan zihin dünyasının doğal bir sonucu olacaktır.

İnsanın metafizikle olan ilişkisi daha çok ahlaki düzlemde tartışılmıştır. İyi kavramının hem felsefi hem de fitri açıdan bireyin ben idrakinin zirvesi olması ve aynı zamanda üst bir varlıkla kurulan ilişkide bir bağlantı noktası olması, kavramın her zaman düşünce dünyasında önemli olmasını sağlamıştır. Aristo'nun mutlulukla eş saydığı iyi kavramı, başka bir şeye araç olmamak ve kendi kendine yeter olmak özelliklerinin yanında, gerçekleşmesinin logos'a uygun bir etkinlikle olması şeklinde izah edilen yönü, sonraki düşünürlerde kavramı oldukça ayrıcalıklı k1lmıştır. ${ }^{68}$ Nitekim Kant sisteminin merkezine iyi kavramını yerleştirmiş, klasik metafizik yerine ahlak metafiziğini inşa ederken bu kavramı kullanmıştır. Aynı

64 Özcan, Insan Felsefesi, 18.Özcan, Insan Felsefesi, 18.

65 Platon, Devlet, 46 (353b).

66 Platon, 202-204 (518a-e).

67 Gülnihal Küken, Felsefe Açısından Eğitim (İstanbul: Alfa Yayınları, 1996), 20.

68 Kuçuradi, İnsan ve Değerleri, 84. 
kavram eğitim ve metafizik bağlantısının en önemli noktasını teşkil etmektedir. Başlı başına bir gelişme ve insan oğluna yapılabilecek en büyük iyiliklerden biri olan eğitim faaliyetinin, duygu ve akıl dünyasının üzerine inşa edildiği metafizik bağlantının zemini de aynı şekilde, bizi zihni olarak doygunluğa götürecek olan iyi kavramına göre bir eğitim faaliyeti yapabilme imkânımızdır.

Platon Devlet 'te her insanın kendi yaradılışına/tabiatına uygun olanı keşfetmesi gerektiğine vurgu yapar. Aslında kişinin kendini tanıması bir anlamda ruhunu tanımasıdır. Eğitimde aslında ruhun sahip olduğu güçleri iyiden yana kullanmasıdır ve bunun için gerekli olan yolu bulma sanatıdır. ${ }^{69}$ Ruh insanın metafiziğe açılan kapısıdır. Eğitim ise ruhun metafizikle buluşmasında ona önderlik eden bir tür sanattır. İşte insan olmaklık durumunun en önemli başarısı, bilinçli bir eğitimle bireyin zihin dünyasını şekillendiren metafizik bir bakış ve zihniyetin oluşmasıdır. Bu bakış hayatın tüm alanlarında bireyleri bilinçli ve diğerkâm yapacaktır. Aristo’ya göre eğitim faaliyetinin en önemli yanı alışkanlıklar kazanmaktır. İyi ve erdemli olmanın yollarını izah ederken bunların alışkanlıktan başka bir deyişle eğitimden geçtiğini ifade etmektedir. İnsan bir takım niteliklerle doğabilir ancak insan sonradan eğitim ve alışkanlıklarla bunları daha iyi ya da kötü yönde ilerletebilir. Tüm bunları ona bahşedilen aklını kullanmasına bağlı olarak olumlu ve olumsuz şekilde devam ettirecektir. Erdemli tercihlerin meydana gelmesi aklını doğru ve doğaya uygun bir şekilde kullanmasına bağlıdır. ${ }^{70}$ Eğitim de doğru kullanım imkânını bize sağlayan araçların başında gelmektedir. Bu nedenle eğitim faaliyetini yürüten eğitici ile öğrenci arasında var olan nedensel ilişki, doğru ve istendik sonuçların meydana gelmesinde yadsınamaz bir etkisi vardır. Eğitici öğrencinin psişik yapısına etki etmekte, onu adeta hamur gibi yoğurmakta, varlığında olan özü keşfederek, Sokrates’teki gibi içindeki özün doğmasına, kendine has bir form almasına, metafizik özle tanışmasına ve kendini gerçekleştirmesine de yardımcı olmaktadır. ${ }^{71}$ Öğretmen burada büyük bir sanatçı, yetiştirdiği öğrencilerde onun en büyük sanat eserleridirler.

Eğitim belli amaçlar muvacehesinde insani yetiştirme ve güdüleme faaliyetidir. Varlığa dair en önemli düşünme/felsefi faaliyet olan metafizik ise başta insanın kendisi olmak üzere külli olarak varlık üzerine düşünme kendi hakikatiyle yüzleşmesi anlamına gelmektedir. Eğitimin metafizik bir boylamla olan ilişkisi ise bu yüzleşmenin, tamamıyla bağımsız, yetkin ve iyi eğitilmiş bir birey yetişme imkânını bize sağlayacaktır. Nihayetinde eğitim de metafizik de asıl olarak insan

69 Platon, Devlet, 202-203 (518a-d).

70 Aristoteles, Politika, 219-20.

71 Ahmet Cevizci, Eğitim Felsefesi (İstanbul: Say Yayınları, 2018), 254. 
varlığına dair bir eylemde bir araya gelmektedirler. Varlığın anlamını keşfetmek insanın kendisini keşfetmektir. Tıpkı Heidegger'deki gibi eğitim ve öğrenme aslında bireyin dasein'i/varlığı keşfetmesi için iki önemli teknik unsurdur. O eğitimi düşünmenin bir sonucu olarak görmektedir. Düşünebilen ve akıllı bir varlık olan insanın ilerlemesi/tekamülü düşünmeyle açılır ve ondaki varlığa dair uğraş nihayetinde bizi dasein'e götürür. Eğitimin metafizikle olan ilişkisinde insanın bilinçli düşünen bir canlı olması durumu anlaşılmadan onun ontik ve epistemik boyutuna dair söylenen her şey gündelik ve dönemlik anlamları dışında kuşatıcı bir bilgi vermekten uzaktır. ${ }^{72}$ Metafizik anlamda mevcudiyetimizin bizi kuşattığı her anda, bilme eyleminin bize sağladığı imkân ve eğitimle açılan her kapı, aslında insanın kendi olması yolunda ona sağlanan bir imkândır. Bu imkân günümüze değin, bazen idealist çoğunlukla da realist bir yorumla ortaya konmuştur. Ancak son dönemler hariç metafizik söylem, her iki yorumda da kendine oldukça önemli bir yer edinmiştir. Yeniçağla birlikte metafiziksel anlam ve söylemin yerini daha çok pratik bir epistemoloji almıştır. Rousseau ve Dewey'de gördüğümüz gibi klasik metafizik söylem eleştirilerek, pratik çözümler öncelenmiştir. ${ }^{73}$

Klasik metafizik söylemi imkân bakımından eleştirip, ahlak bağlamında metafiziğe yeni bir kapı açan Kant'ın eğitim bağlamında ortaya koyduğu görüşler oldukça dikkate değerdir. Eğitim ve metafizik ilişkisi Kant'ta daha çok pratik ve teorik bağlamda ahlak üzerinden inşa edilmeye çalışılmıştır. Ona göre birey kendini iyiye götürecek her türlü istidatı geliştirmelidir. İnsanın ödevi kendini geliştirmektir. Kendini yoldan çıkmış bulduğunda ahlaki yasanın boyunduruğuna girerek yoluna devam etmelidir. İnsan eğitime ihtiyaç duyan tek varlık olarak ilk önce ahlaki terbiye ile eğitilmelidir. ${ }^{74} \mathrm{Bu}$ da eğitimin metafiziksel boyutuyla ilgili pratik ve ahlaki bir yönü ifade eder. Talim ve terbiye sayesinde insan kendi tabiatına uygun eylemde bulunabilir. Eğitimin en önemli yanı öğretimdir. Kişi talim ve terbiye sayesinde kanunları bilir sınırlamaları öğrenir. Kendine uygun özgürlük alanlarına dair bilgi onu insani eylemlerde ahlaki sınırlar içinde kalmasını sağlar. ${ }^{75}$ Eğitim ahlak metafiziği ile birleştiğinde sorumlu, bilinçli ve yetkin özgür birey ortaya çıkar. Kant'a göre insan ancak eğitimle insan olabilir. Hayat boyu süren bir süreç olan eğitim, tıpk1 ahlakta olduğu gibi devamlı gelişmeye ve ilkeli olmaya ihtiyaç duyar. İnsan eğitim sayesinde ilerleyerek kendi bireysel mükemmelliğini

72 Ömer Mahir Alper, Varlık ve İnsan: Kemalpaşazâde Bağlamında Bir Tasavvurun Yeniden İnşası (İstanbul: Klasik Yayınları, 2010), 25.

73 Gerarld L. Gutek, Eğitime Felsefi ve İdeolojik Yaklaşımlar, çev. Nesrin Kale (Ankara: Ütopya Yayınlar1, 2019), 76-77, 103.

74 Immanuel Kant, Eğitim Üzerine: Ruhun Eğitimi-Ahlak Eğitim- Pratik Eğitim, çev. Ahmet Aydoğan (İstanbul: Say Yayınları, 2013), 31.

75 Kant, 32-33.Kant, 
elde eder. ${ }^{76} \mathrm{Bu}$ amaca ulaşmada zihin dünyasını şekillendiren metafiziksel anlam her zaman onun için bir amaçtır. Bu amacın gerçekleşmesi demek, bireylerin ahlaki eğitimlerinin en önemli çıktılarına kavuşmaları demektir. Eğer ahlaki eğitim ihmal edilirse, insanlardaki kusurlar kökleşir, gelecekte karşılaşacağı problemlere karşı güçsüz kalır. ${ }^{77}$

Kant ruhun eğitimi ile ahlaki eğitimi birbirinden ayırmaktadır. Ruha dair eğitim insanın tabiatındaki gelişmeleri, ahlaki eğitim ise özgürlüğünü gaye edinir. İnsanın kendine gerçekleştirebilmesi için hem bir iyi ruha ve bedene, hem de ahlaki olarak iyi olmaya ihtiyacı vardır. Maksimler üzerine kurulu olan ahlak düşüncesi aynı zamanda bireyi geliştiren bir şahsiyet meselesidir. Bu şahsiyet aslında bireyin eğitimle kazandığı gelişimin ahlak metafiziği bağlamında ulaştığı en önemli çıktıdır. Aslında eğitimin en önemli amacı kişiliğimizin teşekkülüdür. ${ }^{78}$

Eğitimin yadsınamaz önemine vurgu yapmaya çalışan Lessing, eğitimin insan tekine verilen bir vahiy gibi olduğunu söyler. Külli olarak eğitim faaliyetinin etkisini, vahyin geldiği toplumdaki etki ile kıyaslayarak, insan için eğitim neyse bütün insanlık için de vahiy odur, diye konunun önemine vurgu yapar. ${ }^{79}$ Locke açısından eğitimin en önemli yanı bireye erdemli olmayı öğretmektir. Bu açıdan eğiticilerin iyi ve erdemli olması onların yetiştirdiği nesillerin de erdem ve bilgelik prensiplerine sahip olmasını sağlayacaktır. ${ }^{80}$ Eğitim asıl amacı olan insan olmayı ögretme ancak bilge ve erdemli birey olma ülküsüyle ortaya koyulabilir bir şeydir. $\mathrm{Bu}$ ise eğitim faaliyetinin yüce amaçlar üzerine inşa edildiği metafizik anlam ve eylem ülküsüyle mümkündür.

\section{Sonuç}

Eğitim, insanın deneyim, görgü ve becerilerini geliştirmeyi ve istendik sonuçlara ulaşmayı amaçlayan, ömür boyun süren bir süreçtir. Metafizik, var olmak bakımından varlığa dair bir sorgulamadır. Eğitim bu sorgulamanın planlı bir şekilde yapılmasını sağlar. Bilinçli bir varlık olan insan eğitimin hem öznesi ve nesnesi, hem de metafizik hakikatin önemli bir unsurudur. İnsan olmaklık demek aslında öğrenebilen bir varlık olmak demektir. Bilinçli bir eğitimin tek muhatabı olan insanın, ontik ve epistemik varoluşunun zirvesi, onun metafizik bir bilince

76 Kant, 35.

77 Kant, 55.

78 Kant, 114-16.

79 Gotthold Ephraim Lessing, İnsan Soyunun Eğitimi Aydınlanma, Din ve Eğitim, çev. Ahmet Aydoğan (İstanbul: Say Yayınları, 2011), 91.

80 John Locke, Eğitim Üzerine, çev. Aylin Uğur (Ankara: Yeryüzü Kitabevi, 2004), 62-63. 
ve kendi zihinsel bağımsızlığına kavuşmasıyla mümkündür. Zira insan eğitimin öznesi ve nesnesi olarak tarih boyunca düşünce dünyasında kendine yer bulmuş, medeniyetler inşa etmiştir. Başardığ 1 ve yok ettiği her şeyde aldığ1 eğitimin, kendi kimliğine yüklemlediği metafiziksel anlamın rolü çok büyüktür. Dünyadaki tüm faaliyetlerde, savaşlarda, sanat ve ilim eserlerinde insanın eğitimle olan değişimi ve dünyada kendine yarattığı ontik metafizik anlamın da yeri büyüktür. Bazen bir kul, bazen de dünyevi bir Tanrı gibi eylemde bulunan insan, bilgi ile mücadelesinde daima ilerlemekte ve hem kendini hem de bu alemi değiştirmektedir.

Her ne kadar yeniçağla birlikte ciddi bir değişime uğrasa da, insana dair en yaygın görüş onun akıl ve ruh sahibi, düşünebilen, teorik ve pratik erdemleriyle bilge olabilen, irade sahibi bir varlık olduğudur. Akıl ve ruh dualitesi insanın metafizikle olan ilişkisini sağlayan bağ gibidir. İnsanın psişik yönüne olan vurgunun zayıfladığı dönemlerde, akıl ve ahlak üzerinden inşa edilen bir metafizik söylemle, insanın kendini tanımladığı dönemler olmuştur. Kant'ın bu anlamdaki yaklaşımının etkinliği hala devam etmektedir. Eğitimin ve bilme eyleminin metafizikle olan bağı, insanı gerçek anlamda özgür kılacaktır. Kur'an'da ‘Âdem olmaklık' durumuyla ifade edilen, özgür/yüce/ontik varlık durumu, insanın sahip olduğu özelliklerin metafizik anlam dünyasıyla taçlandırıldığında ortaya çıkacaktır. Eğitimin, eğitimci ve eğitilen bireyin anlam dünyasında yer bulabilmesi, tabiiyyât ve ilahiyyât ilimlerinin oluşturduğu ontik ve epistemik alanda kendini gerçekleştirmesiyle mümkündür. Bunun aksi olan eğitim anlayışının yetiştirdiği bireyler, iradenin anlamsızlaştığı, gayrı-nâtık canlılar gibi içgüdüsel ya da şartlanmış şekilde hareket edecek ve insanî özelliklerini gerçekleştiremeyecektir.

Bağımsız ve kişilikli bir neslin/insanın yetişmesi ancak metafizik bir anlam üzerinden yürütülen eğitimle mümkündür. Böyle bir eğitimin başarılması, ortaya konulan eğitim faaliyetinin yapısı kadar, eğitici rolünü üstlenen öğretmenin/hocanın insani yetkinliğiyle de doğrudan ilgilidir. Sadece nicel verilere, ideolojik kaygılara ve pragmatist amaçlara yönelik yapılan eğitim ve buna yönelik inşa edilen geçici anlam dünyasının beslediği eğitim anlayışının yetiştirdiği insan, zamanla kendini yokeden, narsist, bencil, etik ve insani değer sistemiyle sınırlanmamış bir birey olacaktır. Buna karşı ortaya konulan yeni bir eğitim politikasının da, anlamdan yoksun bir şekilde yine aynı amaçla, nicel ve hızlı sonuç almak üzerine kurulu olduğu durumda, eğitime bağlı problemler içinden çıkılmaz hal alacak, nesiller arasındaki anlam karmaşası ve mücadelesi biteviye sürecektir. Bundan dolayıdır ki, her siyasi yönetimin muhakkak eğitime dair bir öngörüsü ve politikası vardır. Olması da doğaldır. Ancak bu düşüncelerin insan olmaklık durumuyla ilişkilendirilmediği ve bunda ısrarcı olunmadığında, bizatihi yetişen yeni nesil kendi yöneticilerini eleştirecek ve o toplumun bizatihi felaketi olacaktır. Bu nedenle insanın sınırları 
olan bir Âdem olduğunu hiçbir zaman unutmamak gerekmektedir. Çağdaş dünyanın ve bilimin imlediği sınırları olmayan bakışın, ideolojik kaygılarla birleştiği alanda insan, imar edici olmaktan çok yok edici bir varlık olmaya da mahkumdur. Bu nedenle indirgemeci, ötekileştirici tüm bakış açılarına karşı insana bizatihi öğrenme imkânını vermek ve onun insani değerlerini gerçekleştirebilmesini ummaktan başka bir çaremiz yoktur. Biyo-psişik bir varlık olarak bilinç ve ahlaklılık bizi aslında insan yapan en önemli özelliklerdir. Bunların metafizik anlam ile her an canlı tutulması gerekmektedir. Aksi takdirde bilincin olmadığı güdülenmiş bir eğitimin öznesi olan insanlar, çözüm üretmek bir yana bizatihi problemin de müsebbipleri olacaktır. Sorumluluk bilinciyle kuvvetlendirilmiş insanî özgürlük, ontik/metafizik bir anlamla birleştiğinde insan, işte o zaman gerçek anlamda bilge/hikmetli bir insan, irfanî anlamda gerçek özgür birey olacaktır.

Hakem Değerlendirmesi: Dış bağımsız.

Çıkar Çatışması: Yazar çıkar çatışması bildirmemiştir.

Finansal Destek: Yazar bu çalışma için finansal destek almadığını beyan etmiştir.

Peer-review: Externally peer-reviewed.

Conflict of Interest: The author has no conflict of interest to declare.

Grant Support: The author declared that this study has received no grant support.

\section{Kaynakça/References}

Alper, Ömer Mahir. Varlık ve İnsan: Kemalpaşazâde Bağlamında Bir Tasavvurun Yeniden İnşası. İstanbul: Klasik Yayınları, 2010.

Aristoteles. Metafizik. Çeviren Ahmet Arslan. İstanbul: Sosyal Yayınları, 2010.

—. Nikomakhos 'a Etik. Çeviren Saffet Babür. Ankara: Ayraç Yayınları, 1997.

—. Politika. Çeviren Mete Tunçay. İstanbul: Remzi Kitabevi, 1993.

Ruh Üzerine. Çeviren Ömer Aygün ve Y. Gurur Sev. İstanbul: Pinhan Yayınları, 2019.

Aydın, Mehmet Zeki. “Sokrates'in Doğurtma (Buldurma) Yöntemi”. İçinde Doğudan Batıya Düşüncenin Serüveni, editör Celal Türer ve Hakan Olgun, 1. bs, 2:141-54. İstanbul: İnsan Yayınları, 2015.

Canatan, Kadir. İnsan Felsefesi. İstanbul: Beyan Yayınları, 2018.

Cassirer, Ernest. Insan Üstüne Bir Deneme. Çeviren Necla Arat. İstanbul: Remzi Kitabevi, 1980.

Cevizci, Ahmet. Eğitim Felsefesi. İstanbul: Say Yayınları, 2018.

Çağbayır, Yaşar. Ötüken Türkçe Sözlük. C. 2.5 c. İstanbul: Ötüken Yayınları, 2007.

Çetinkaya, Bayram Ali. Felsefe Tarihi Antik Doğu'dan Modern Batı'ya. Ankara: Nobel Yayıncılık, 2017.

Demirkol, Murat. “13. Yüzyılın Bilge ve Kelamcı Filozofu Nasireddin Tûsi”. İçinde İslam Felsefesi El Kitabl, editör Bayram Ali Çetinkaya, 283-302. Ankara: Grafiker Yayınları, 2017. 
Deniz, Gürbüz. İnsan Hürriyetinin Metafizik Temelleri. İstanbul: Litera Yayınc1lık, 2017.

Descartes, René. Ruhun İhtirasları. Çeviren Mehmet Karasan. İstanbul: Milli Eğitim Bakanlığı Yayınlar1, 1997.

Durusoy, Ali. “İbn Sînâ Felsefesi’nde İnsan”. İçinde Doğu’dan Batıya Düşüncenin Serüveni, editör Abdullah Kahraman, 1. bs, 5:971-80. İstanbul: İnsan Yayınları, 2015.

Erden, Münire. Eğitim Bilimlerine Giriş. Ankara: Arkadaş Yayınları, 2011.

Ergün, Mustafa. Ĕgitim Felsefesi. Ankara: Pegem Akademi, 2015.

Fârâbî, Ebu Nasr el-. Farabî’nin Üç Eseri: Mutluluğu Kazanma (Tahsilu's-Sa'ade) Eflatun Felsefesi ve Aristo Felsefesi. Çeviren Hüseyin Atay. Ankara: Ankara Üniversitesi İlahiyat Fakültesi Yayınları, 1974.

—. Ideal Devlet: "el Medinetü'l Fâzıla". Çeviren Ahmet Arslan. Ankara: Divan Kitap, 2015.

Giladi, Avner. "Islamic Educational Theories in the Middle Ages: Some Methodological Notes with Special Reference to al-Ghazali”. British Society of Middle Eastern Studies 14, sy 1 (1987).

Gutek, Gerarld L. Eğitime Felsefi ve İdeolojik Yaklaşımlar. Çeviren Nesrin Kale. Ankara: Ütopya Yayınları, 2019.

Hafiz, Muharrem. "Platon ve Siyâset Felsefesi”. İçinde Doğudan Batıya Düşüncenin Serüveni, editör Celal Türer ve Hakan Olgun, 1. bs, 2:167-90. İstanbul: İnsan Yayınlar1, 2015.

İbn Sînâ. Kitâbu'ş-Şifa (Metafizik). Çeviren Ekrem Demirli ve Ömer Türker. İstanbul: Litera Yayıncılık, 2004.

Kant, Immanuel. “Aydınlanma Nedir? Sorusuna Yanıt (1784)”. Çeviren Nejat Bozkurt. Toplumbilim Aydınlanma Özel Sayısl, sy 11 (Temmuz 2000).

—. Ĕ̌gitim Üzerine: Ruhun Eğitimi-Ahlak Eğitim- Pratik Eğitim. Çeviren Ahmet Aydoğan. İstanbul: Say Yayınları, 2013.

Kayacık, Ahmet. "Bağdad Okulu”. İçinde Doğudan Batıya Düşüncenin Serüveni, editör Abdullah Kahraman, 1. bs, 5:265-76. İstanbul: İnsan Yayınları, 2015.

Koç, Ahmet. "İhvân-1 Safâ ve Eğitim”. editör İsmail Çalışkan, 1. bs. C. 6. İstanbul: İnsan Yayınları, 2015.

Kranz, Walter. Antik Felsefe. Çeviren Suat Baydur. İstanbul: Sosyal Yayınları, 1984.

Kuçuradi, İonna. Etik. Ankara: Türkiye Felsefe Kurumu, 2006.

—. Insan ve Değerleri. Ankara: Türkiye Felsefe Kurumu, 2013.

- Nietzsche ve İnsan. İstanbul: Yank1 Yayınları, 1967.

Kutluer, İlhan. "İnsan”. İçinde TDV İslâm Ansiklopedisi, 22:320-23. Ankara: Türkiye Diyanet Vakfi Yayınları, 2000.

Küken, Gülnihal. Felsefe Açısından Eğitim. İstanbul: Alfa Yayınları, 1996.

Lessing, Gotthold Ephraim. Insan Soyunun Eğitimi Aydınlanma, Din ve Eğitim. Çeviren Ahmet Aydoğan. İstanbul: Say Yayınları, 2011.

Locke, John. Eğitim Üzerine. Çeviren Aylin Uğur. Ankara: Yeryüzü Kitabevi, 2004.

Mengüşoğlu, Takiyyüddin. İnsan Felsefesi. İstanbul: Doğu Batı Yayınları, 2017.

Nietzsche, Friedrich. Böyle Söyledi Zerdüşt. Çeviren Mustafa Tüzel. Hasan Âli Yücel Klasikler Dizisi. İstanbul: Türkiye İş Bankası Kültür Yayınları, 2016.

Özcan, Muttalip. İnsan Felsefesi: İnsanın Neliği Üzerine Bir Soruşturma. Ankara: Bilgesu Yayıncılık, 2016. 
Platon. Devlet. Çeviren Sabahattin Eyüpoğlu ve M.Ali Cimcoz. İstanbul: Remzi Kitabevi, 1992.

__. "Gorgias”. İçinde Diyaloglar, çeviren Melih Cevdet Anday. İstanbul: Remzi Kitabevi, 2010.

—_. "Kharmides”. İçinde Diyaloglar, çeviren Tanju Gökçöl. İstanbul: Remzi Kitabevi, 2010.

_. "Menon”. İçinde Diyaloglar, çeviren Adnan Cemgil. İstanbul: Remzi Kitabevi, 2010.

—. Phaidon (Ruh Üstüne). Çeviren Nazife Kalaycı. İstanbul: Kabalcı Yayınevi, 2012.

—. "Theaitetos”. İçinde Diyaloglar, çeviren Macit Gökberk. İstanbul: Remzi Kitabevi, 2010.

Platon, ve Teoman Aktürel. “Sokrates'in Savunması”. İçinde Diyaloglar. İstanbul: Remzi Kitabevi, 2010.

Scheler, Max. Innsanın Kozmos 'taki Yeri. Çeviren Tomris Mengüşoğlu. İstanbul: Yaprak Yayınları, 1988.

Twain, Mark. İnsan Nedir? Çeviren Esra Şimşek. İstanbul: Turkuaz Kitap, 2020.

Wilson, Edward O. İnsanın Varlı̆̆ının Anlamı. Çeviren Zeynep Sezer. İstanbul: Olvido Yayınları, 2017. 